\title{
Protesto, insubordinação e reminiscências da escravidão na construção da ferrovia Bahia-Minas na década da abolição*
}

\author{
Protest, Insubordination, and Slavery Reminiscences in the \\ Building of the Bahia-Minas Railway in the Emancipation Decade
}

\section{lacy Maia Mata* Robério Santos Souza ${ }^{* * *}$}

\begin{abstract}
Resumo: Em 1888 foi abolida a escravidão no Brasil. A década da abolição, no extremo sul da Bahia, foi acompanhada de conflitos e tensões envolvendo senhores, escravos, abolicionistas e autoridades provinciais. A este cenário se somou a presença de uma multidão de trabalhadores para a construção da estrada de ferro Bahia-Minas, oriundos de várias regiões. Os operários que construíam a ferrovia protagonizaram uma série de protestos, motins e reivindicações ao longo da década, contribuindo para o "clima de instabilidade" que marcou as lutas em torno da escravidão e da liberdade na região. Em 1888, depois da aprovação da lei de 13 de maio, após um protesto armado, uma turma de trabalhadores portugueses engajados nas obras da estrada de ferro foi presa no tronco e permaneceu durante meses na prisão. Este artigo, através da documentação policial e judicial, analisa este episódio e discute as reminiscências escravistas nas relações de trabalho na ferrovia no período imediato à abolição.
\end{abstract}

Palavras-chave: Trabalhadores da construção; pós-abolição; reminiscências da escravidão.

* Este trabalho contou com o apoio do Programa ProPesq UFBA/MCTI e da Fundação de Amparo à Pesquisa do Estado da Bahia (FAPESB). Os autores agradecem ao pesquisador Urano de Cerqueira Andrade pelo inestimável auxílio no Arquivo Público do Estado da Bahia (doravante APEB).

** Doutora em História Social pela Universidade Estadual de Campinas (Unicamp). Professora Adjunta do Departamento de História, da Universidade Federal da Bahia (UFBA). ORCID: https://orcid.org/0000-00022790-9623. E-mail: iacymaia@yahoo.com.br.

*** Doutor em História Social pela Universidade Estadual de Campinas (Unicamp). Professor Titular do Departamento de Ciências Humanas, da Universidade do Estado da Bahia (UNEB). ORCID: https://orcid. org/0000-0002-5380-3363. E-mail: roberiossouza@gmail.com. 
Abstract: In 1888, slavery was abolished in Brazil. The emancipation decade, in the far South of Bahia, was accompanied by conflicts and tensions involving masters, slaves, abolitionists, and provincial officials. Adding to this setting was the presence of a multitude of workers from several places in for the building of the Bahia-Minas railway. These workers put forth a host of protests, mutinies, and claims along the decade, contributing to the "atmosphere of unrest" which marked the struggles around slavery and freedom in the region. In 1888, after the May $13^{\text {th }}$ emancipation law was approved, a crew of Portuguese construction workers were tied to trunks as a punishment for an armed protest, and were kept in prison for months. This paper analyses this episode and discusses slavery reminiscences in labor relations in the railway construction just after emancipation, drawing upon police and judicial documents.

Keywords: Construction workers; post-abolition; reminiscences of slavery.

\title{
Introdução
}

\begin{abstract}
A CONSTRUÇÃO dA ESTRAdA dE FERRO BAHIA-MInAs foi autorizada pela Lei Provincial de $\mathrm{n} .^{\circ}$ 1.946, de 1879. O engenheiro Miguel de Teive e Argollo, oriundo da família aristocrática Teive e Argollo, dona de escravos e terras na província da Bahia, obteve a concessão de 50 anos para executar a obra de construção e explorar economicamente a ferrovia. ${ }^{1} \mathrm{~A}$ linha férrea Bahia-Minas partia da cidade de Caravelas, atravessava as diversas localidades que faziam divisa com a província da Bahia e encontrava a estrada de ferro ao norte de Minas Gerais. O contrato para a construção e início das obras foi celebrado pelo presidente da província Antônio de Araújo Aragão Bulcão, o barão de São Francisco, e por Miguel de Teive e Argollo, engenheiro concessionário, em 19 de julho de 1880. Para levar adiante a construção da ferrovia, o concessionário ainda se associou aos empresários do Rio de Janeiro, capital do Império, passando a empresa a se chamar Companhia da Estrada de Ferro Bahia e Minas.
\end{abstract}

1 Sobre o engenheiro Miguel de Teive Argollo e sua atuação na implantação de empreendimentos ferroviários na Bahia, cf. SOUZA, Robério S. Tudo pelo trabalho livre: trabalhadores e conflitos no pós-abolição (Bahia, 1892-1909). Salvador/São Paulo: Edufba/Fapesp, 2011. Cap. 1. 


\section{Mapa 1 - Sul da Bahia na segunda metade do século XIX.}

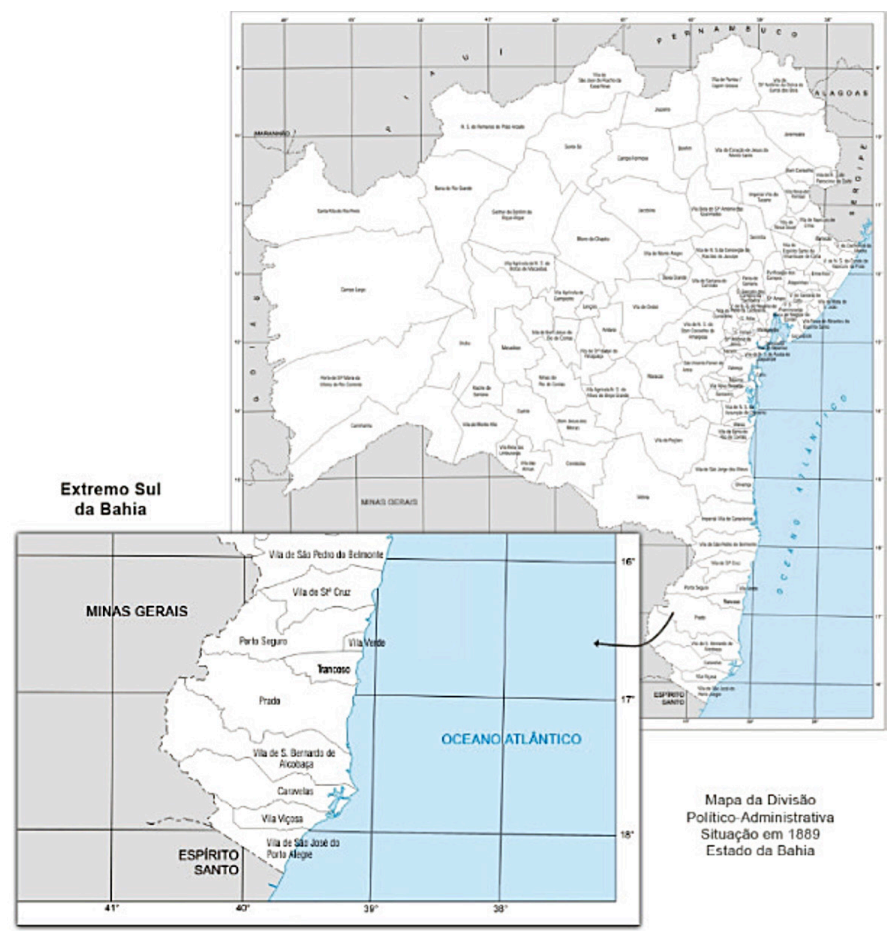

Fonte: Evolução territorial e administrativa do estado da Bahia. Um breve histórico. Salvador: SEI, 2003 apud SILVA, Ricardo Tadeu Caires. Criminalidade, resistência escrava e abolicionismo na Colônia Leopoldina, Bahia (1880-1888). Revista de História Regional, Ponta Grossa, v. 1, n. 21, p. 83-109, 2016.

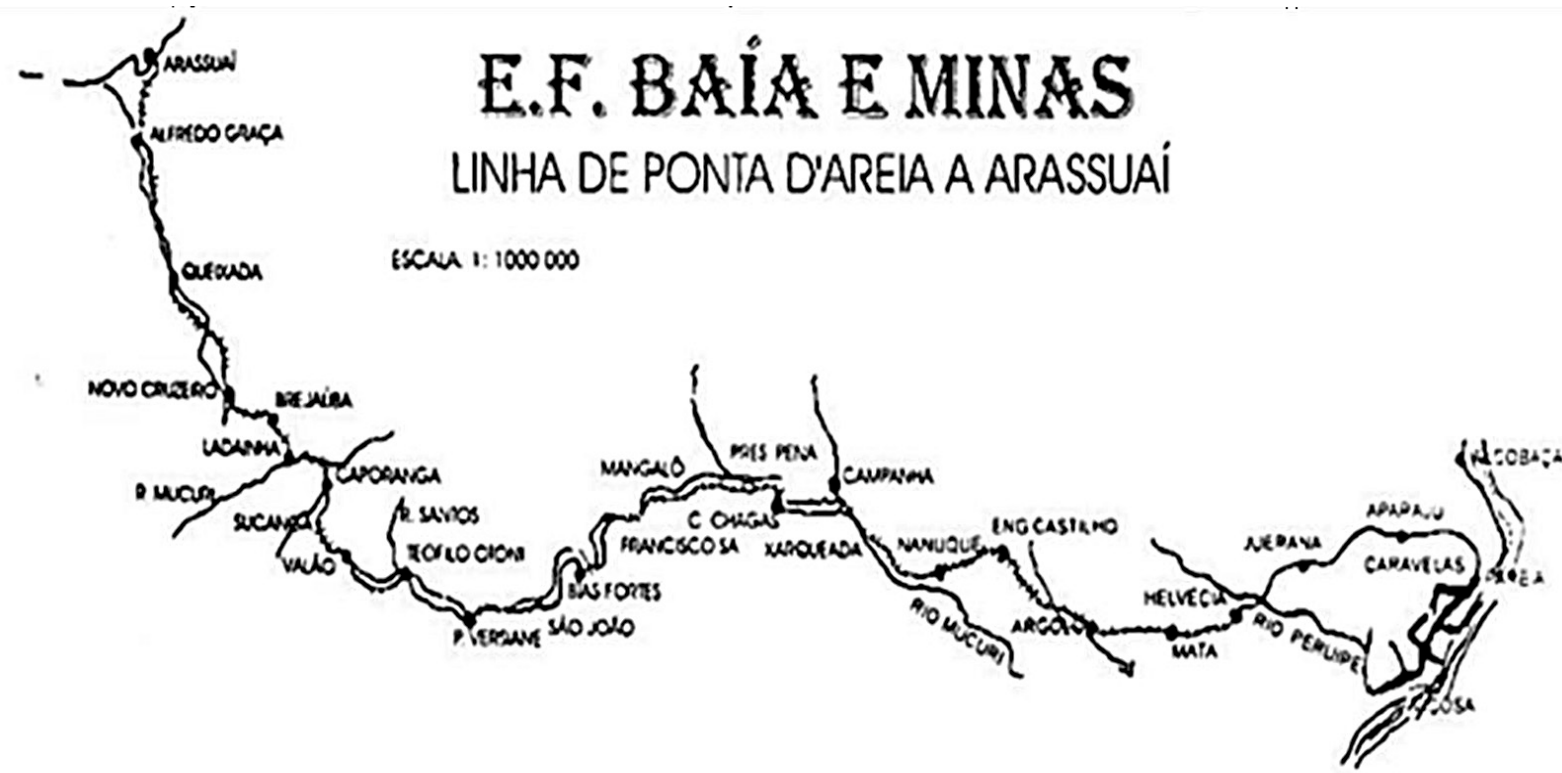

Fonte: Ministério da Viação e Obras Públicas, 1949 apud MELO, Cleiton Jones. "Vem aí a imigração": expectativas, propostas e efetivações da imigração na Bahia (1816-1900). 2014. Dissertação (Mestrado em História) - Faculdade de Filosofia e Ciências Humanas, Universidade Federal da Bahia, Salvador, 2014. 


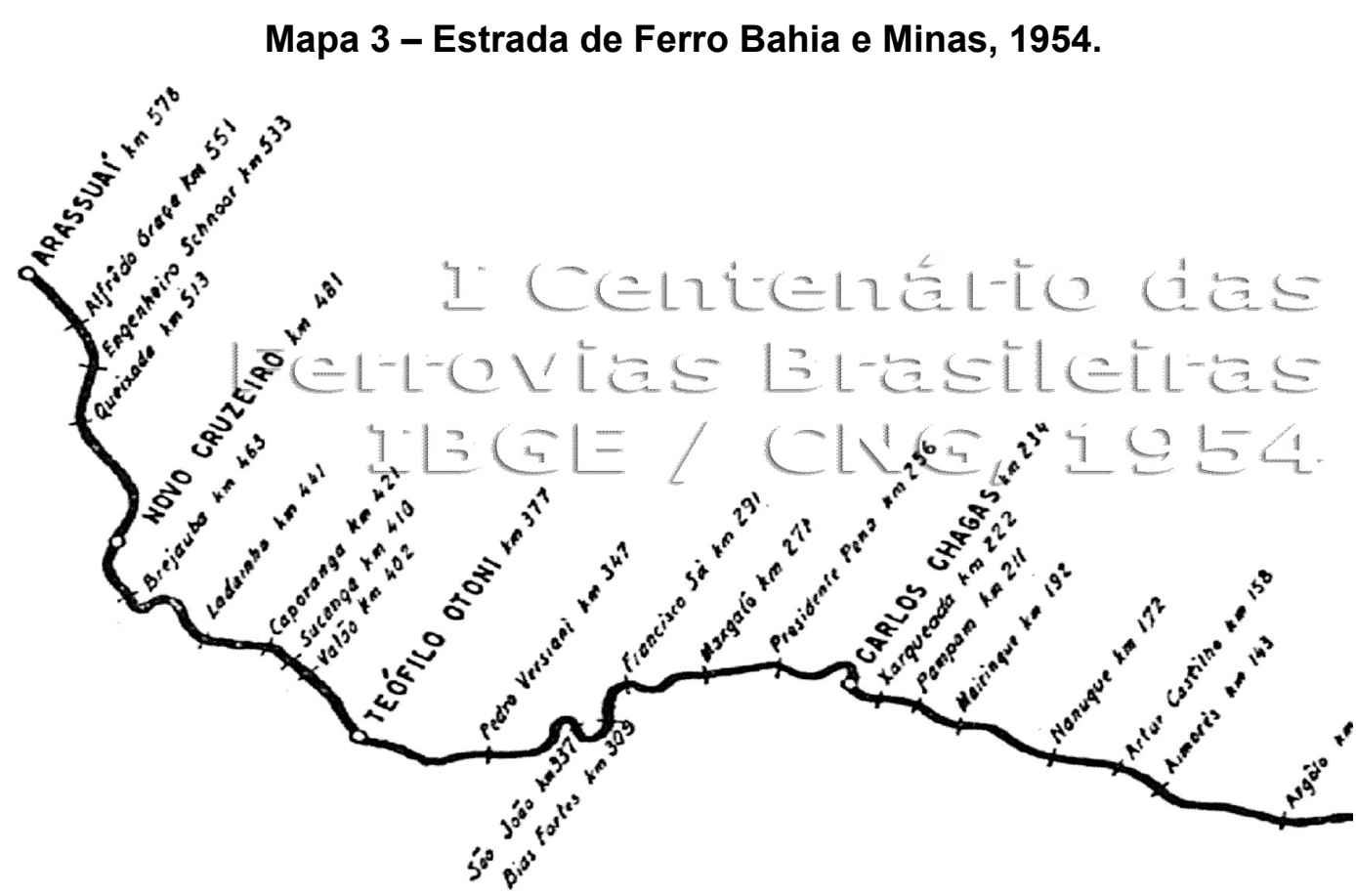

Disponível em: http://vfco.brazilia.jor.br/mapas-ferroviarios/1954-EF-Bahia-e-Minas.shtml. Acesso em: 29 dez. 2016.

Para dinamizar economicamente a linha férrea principal, o contrato de construção previa que o concessionário "abrisse uma estrada de rodagem, que ligasse a linha férrea à povoação da Barra de Caravelas". ${ }^{2}$ A partir de Caravelas, a linha férrea atravessaria a parte sul da província da Bahia em 142 quilômetros. Em 9 de novembro de 1882, foi inaugurado o trecho da linha férrea que ia até a Serra de Aymorés, região limítrofe com a província de Minas Gerais. Como foi comum a outras companhias ferroviárias espalhadas pelo país, a ferrovia Bahia-Minas foi sendo construída por seções, recrutando trabalhadores para as diversas obras. Neste artigo analisaremos protestos e repressões aos trabalhadores engajados nas obras da estrada de ferro Bahia-Minas, especificamente no trecho de Ponta de Areia, Caravelas e Aymorés.

Além de certo número de trabalhadores qualificados, a construção de estradas de ferro e de seus prolongamentos demandava o engajamento de um volumoso contingente de trabalhadores braçais e sem qualquer tipo de especialização, incumbidos de executar os serviços e as atividades pesadas nos canteiros de trabalho. ${ }^{3}$ Segundo Maria Lúcia Lamounier, "os trabalhadores na construção precisavam de pouca habilidade, além de 'bater o prego com o martelo [...] [a qual] era universalmente considerada a mais inferior e

2 Estrada de Ferro Bahia-Minas, S/D, série viação, maço 4982, APEB.

3 Sobre a natureza do trabalho e a predominância do trabalho braçal nas obras de construção ferroviária, cf. CECHIN, José. A construção e operação das ferrovias no século XIX. 1978. Dissertação (Mestrado em História) - Instituto de Filosofia e Ciências Humanas, Universidade Estadual de Campinas, Campinas, 1978; LAMOUNIER, Maria Lúcia. Ferrovias e mercado de trabalho no Brasil do século XIX. São Paulo: Editora da USP, 2012; MORATELLI, Thiago. Operários de empreitada. Os trabalhadores da construção da estrada de ferro Noroeste do Brasil (São Paulo e Mato Grosso, 1905-1914). Campinas, SP: Editora da Unicamp, 2013; e SOUZA, Robério S. Trabalhadores dos trilhos: imigrantes e nacionais livres, libertos e escravos na construção da primeira ferrovia baiana (1858-1863). Campinas: Editora da Unicamp, 2015. 
árdua forma de trabalho'. Até o final do século XIX, as principais ferramentas utilizadas na construção eram pás, picaretas e pólvora" ${ }^{4}$

Espalhados por diferentes locais das regiões atravessadas pela linha férrea, os trabalhadores da construção se deslocavam conforme o progresso das obras. Em relação às condições de moradia, os trabalhadores eram muitas vezes abrigados em alojamentos coletivos precários, conhecidos como barracões. Eles podiam ter diferentes vínculos com a empresa: havia aqueles que eram contratados diretamente pelas companhias; e havia os trabalhadores avulsos, em sua maioria, recrutados pelos empreiteiros, subempreiteiros ou tarefeiros encarregados pelos trechos, serviços ou seções nas obras. ${ }^{5}$ As ferrovias, em que pese suas peculiaridades, seguiam o padrão comum a outras experiências de construção de obras dessa natureza.

No Brasil, ao longo do século XIX e no início do século XX, as ferrovias foram construídas a partir do recrutamento de uma multidão diversa de estrangeiros e nacionais. Esse engajamento de trabalhadores brasileiros e imigrantes nas estradas de ferro na Bahia no século XIX já foi investigado pela historiografia ${ }^{6}$ e a experiência da "multidão" marcada pela diversidade parece também se repetir no sul da Bahia no final do século XIX. É o que revela Cleiton Jones Melo em seu estudo sobre imigração na Bahia: a Bahia-Minas, assim como fizeram outras companhias do país, recrutou imigrantes para as obras da estrada de ferro. Segundo ele, o jornal Gazeta da Tarde, sediado no Rio de Janeiro, apontava que a Companhia Bahia-Minas "contratara em 1883, junto à firma de importação de imigrantes Agostinho Pires \& Cia., uma remessa de espanhóis das Ilhas Canárias, de preferência em família, para os trabalhos da linha férrea". 7 Além dos imigrantes espanhóis citados por Melo, entre os recrutados para as obras e os canteiros da construção da ferrovia Bahia-Minas estavam portugueses, italianos e brasileiros, inclusive vindos de várias regiões do país, a exemplo de mineiros, paulistas e pernambucanos. ${ }^{8}$ Segundo um jornal baiano, a estrada de ferro Bahia-Minas reunia "gente de todo calibre" no extremo sul da Bahia. ${ }^{9}$

A presença e o ajuntamento de grande número de trabalhadores nas obras de construção de ferrovias costumava levar preocupação para as autoridades, as elites e a população das diversas localidades do país, que comumente associavam os operários recém-chegados à criminalidade e à desordem social. ${ }^{10}$ Essa percepção deixou registro nas narrativas contemporâneas, nos jornais e na documentação policial. Em 1859 as autoridades policiais

4 Cf. LAMOUNIER, Maria Lúcia. Ferrovias, agricultura de exportação e mão de obra no Brasil no século XIX. História econômica e história de empresas, São Paulo, v. 3, n. 1, p. 43-76, 2000.

5 MORATELLI, op. cit.

6 SOUZA, op. cit., 2015, cap. 2; MORATELLI, op. cit.

7 Cf. MELO, op. cit, p. 163. O autor faz referência à notícia vinculada no jornal Gazeta da Tarde, Rio de Janeiro, n. 38, p. 2, 19 fev. 1883.

8 Denúncia do promotor público Francisco Antonio Carvalhal, correspondência dos chefes de policia, 18681889 , seção colonial e provincial, maço 2986, APEB.

9 Diário da Bahia, Salvador, 14 jun. 1888, APEB.

10 Correspondência de Ernesto José Ferreira, subdelegado de Pirajá, para o chefe de polícia, 8 fev. 1859. Correspondência recebida de subdelegados, maço 6232, APEB. 
de Salvador e das subdelegacias das vilas do interior da província da Bahia, por exemplo, discutiram insistentemente sobre a perigosa presença de trabalhadores indesejáveis que convergiam para as diversas localidades que abrigavam as obras de construção da linha férrea da Bahia ao São Francisco. Em fevereiro daquele ano, o subdelegado Ernesto José Ferreira alertou o chefe de polícia de que na região do Engenho de Periperi, ao longo dos canteiros de trabalho da estrada de ferro, estava se concentrando uma volumosa quantidade de trabalhadores nacionais e estrangeiros "desordeiros e turbulentos" que protagonizavam conflitos e que podiam comprometer a ordem social.

$\mathrm{Na}$ década de 1880, o temor de que os trabalhadores empregados na construção das ferrovias provocassem desordens parece ter sido ainda maior. Em Caravelas e Vila Viçosa, a chegada de centenas de operários para as obras da linha férrea ajudou a compor o cenário de temores e conflitos que marcaram a década da abolição na região. As localidades vinham sendo palco de motins escravos, fugas, assassinato de um senhor, ações de liberdade e do ativismo de um padre abolicionista radical, e a presença de operários migrantes aumentava ainda mais as tensões na região. ${ }^{11}$ Senhores e escravos se enfrentavam em querelas judiciais e os moradores encontravam-se divididos nas disputas políticas (e eleitorais) locais. A este cenário já conturbado se somaria uma multidão de trabalhadores com suas próprias reivindicações, o que agudizaria ainda mais os conflitos e alimentaria o temor da desordem social. Como sinalizamos anteriormente, as acusações de que os trabalhadores recém-chegados eram desordeiros, criminosos, brigões, embriagados, perigosos, insubordinados eram representações comuns nas narrativas policiais e das autoridades provinciais. Não por acaso, um dos contemporâneos perguntou: "Se sabe que existe odiosidade de certas pessoas desta cidade para com o pessoal da estrada de ferro Bahia e Minas e que mais de uma vez se tem procurado envolvê-los em processos criminais?". ${ }^{12}$

\section{Reiterados motins e reivindicações}

SOLICITAÇÕES DE FORÇAS POLICIAIS para conter "distúrbios" provocados pelos operários da construção da ferrovia Bahia-Minas, no decorrer da década de 1880, foram frequentes. Em fins de fevereiro de 1884, um motim envolvendo homens da construção do prolongamento assustou o empreiteiro e as autoridades da cidade de Caravelas. Insatisfeitos com a falta de pagamento, que parece ter sido habitual, e com a situação de fome em que se encontravam, os trabalhadores "assaltaram o trem de passageiros e dirigiram-se para a Estação Central", onde visavam pressionar os administradores da ferrovia para que suas reivindicações fossem atendidas. ${ }^{13} \mathrm{Em}$ um trem expresso, o superintendente da estrada juntamente com outros

11 SILVA, Ricardo Tadeu Caires; MATA, lacy Maia. Resistência e rebeldia: escravidão e pós-abolição no extremo sul da Bahia (1888-1889). [No prelo.]

12 Inquirição dos acusados Felisberto Cabral e Luiz da França à testemunha Henrique Marcolino de Alcântara, delegados, 1884-1889, seção colonial e provincial, maço 302, APEB.

13 Correspondência de Epaminondas Esteves Ottoni, engenheiro fiscal da Estrada de Ferro Bahia-Minas, para o 
cidadãos dirigiram-se para a estação de Juerana, onde se reuniram com os trabalhadores. Apesar das conversações e tentativas de negociação para dissuadi-los, os operários não ficaram convencidos e satisfeitos com as promessas feitas pelo superintendente da companhia e a impasse só deu sinal de avanço com a intermediação de um cidadão chamado Marcelo Pereira Guedes, "que [lhes] garantiu o pagamento integral [dos salários] assim que [chegasse] o vapor da Corte". 14

Embora tivessem sinalizado para a negociação e término do motim, os trabalhadores recuaram em face da possibilidade de acordo quando souberam que a quantia que seria destinada ao pagamento dos salários não havia chegado com os cofres do vapor, conforme acordado. Exaltados, passaram a ameaçar "não só as obras da estrada como as propriedades do Sr. Guedes" ${ }^{15}$ responsável pela negociação. Não temos informações se Marcelo Pereira Guedes, além de proprietário de terras, era também senhor de escravos ou se mantinha negócios com a Companhia da Estrada de Ferro Bahia e Minas. É importante considerar que algumas autoridades locais e proprietários de terras, inclusive escravistas, mantinham relações muito próximas e até mesmo negócios e interesses convergentes com os empresários que administravam as ferrovias. Na região de Caravelas, como em outras partes da província, não foi diferente. $O$ fato de os trabalhadores ameaçarem invadir propriedades era algo realmente preocupante naquele contexto de crescimento do movimento abolicionista e da insubordinação escrava, onde a contestação das prerrogativas senhoriais e da escravidão permeavam as disputas políticas locais.

A ousada ação anunciada por aqueles trabalhadores aterrorizou as autoridades provinciais. Em face disso, o engenheiro fiscal justificou o seu pedido de ajuda para o restabelecimento da ordem, sendo enviado "o capitão Durval Vieira de Aguiar, a quem prouver prestar todas as informações sobre o levantamento e suas causas". ${ }^{16}$ Dias depois, de acordo com o engenheiro fiscal Epaminondas Esteves Ottoni, os trabalhadores foram pagos e todos demitidos, tendo a companhia "resolvido [...] suspender as obras de construção no prolongamento". Assim, fora findado o conflito sem que houvesse "felizmente derramamento de sangue e outros prejuízos a lamentar". ${ }^{17}$

Cleiton Jones Melo identificou um protesto de trabalhadores espanhóis colonos, contratados pela Companhia da Estrada de Ferro Bahia e Minas, ocorrido ainda naquele ano de 1884. Os operários espanhóis evadiram-se das propriedades às margens da ferrovia para denunciar às autoridades as condições adversas às quais estavam submetidos. Como destacou o autor, "os terrenos às margens das ferrovias podiam ser utilizados pelas

conselheiro Pedro Luiz Pereira de Souza, presidente da província da Bahia, 22 de março de 1884. Estrada de Ferro Bahia-Minas, série viação, maço 4982, APEB.

14 Correspondência de Epaminondas Esteves Ottoni, engenheiro fiscal da Estrada de Ferro Bahia-Minas, para o conselheiro Pedro Luiz Pereira de Souza, presidente da província da Bahia, 22 de março de 1884. Estrada de Ferro Bahia-Minas, série viação, maço 4982, APEB.

17 Ibidem. 
companhias para exploração de recursos naturais como para loteamento e colonização". ${ }^{18}$ Não podemos afirmar que esses colonos, além de trabalhar nas terras às margens da ferrovia, fossem engajados nos canteiros de obras da companhia da Bahia-Minas, embora não seja improvável que, uma vez contratados, fossem força de trabalho aproveitada em ambas as frentes da linha férrea. Por fim, não podemos ainda dizer com segurança qual a conexão entre o caso de sublevação dos trabalhadores da construção do prolongamento e o episódio de protesto dos espanhóis em 1884 relatado por Cleiton Jones Melo, sobre o qual o presidente da província afirmou que, aproximadamente 250 imigrantes espanhóis, contratados no Rio de Janeiro a fim de se engajar nas obras da estrada de ferro Bahia- Minas, teriam se deslocado a Caravelas para reivindicar direitos, "em desordem e no maior grau de penúria". ${ }^{19}$

Algumas décadas separam esses trabalhadores imigrantes espanhóis, contratados pela Companhia Estrada de Ferro Bahia-Minas, daqueles operários italianos que foram recrutados mediante contrato para trabalhar nas obras da Companhia Ferroviária da Bahia ao São Francisco, em $1858 .^{20}$ Entretanto, as denúncias de penúria e descumprimento contratual, além de outros aspectos, parecem comuns aos dois grupos recém-chegados no mundo do trabalho ferroviário da sociedade escravista brasileira. Por intermédio de Melo, temos conhecimento de que a companhia comandada por Miguel de Teive e Argollo também desrespeitava e descumpria direitos previstos em várias cláusulas contratuais firmadas com os trabalhadores, como gratuidade da comida por oito meses, casas em boas condições, lotes de terra, assistência médica, produtos alimentícios a preços justos, ferramentas de trabalho etc. Ainda segundo estudo de Melo,

Pelo relatodos colonos, aochegar 'en Campos de Aymorés Estrada de Ferro Baia y Minas donde conocimos que todo lo prometido y asinado en dicho contrato era lo contrario'. O oferecimento da comida, diziam os imigrantes, se dava da seguinte maneira. Cada pessoa recebia por semana três quilos e meio de gêneros entre feijão, arroz e farinha de mandioca, $500 \mathrm{~g}$ de carne seca, quando havia, mais $100 \mathrm{~g}$ de toucinho. O açúcar e o café recebiam apenas uma ou duas vezes por mês. Outra reclamação era da qualidade das habitações. Segundo os trabalhadores, as casas não eram boas, porque eram pequenas (apenas $17,5 \mathrm{~m}^{2}$ cada) e úmidas, e eles viviam amontoados. Por terem sido construídas à beira de um rio, eles sofriam com diversas doenças, como febre e feridas nas pernas, que os impossibilitavam de trabalhar e também pela falta de condições higiênicas, que contribuíam para o aumento das infecções e epidemias. ${ }^{21}$

Ao desembarcar para trabalhar na região escravista do extremo sul da Bahia, esses trabalhadores se deparavam com uma realidade muito distante daquela prevista no contrato firmado com os responsáveis pela Companhia da Estrada de Ferro Bahia-Minas, tornando-se

18 MELO, op. cit., p. 64.

19 Ibidem, p. 63.

20 Sobre a primeira experiência da Bahia, Estrada da Bahia ao São Francisco, cf. SOUZA, op. cit., 2015. Para mais dimensões do protesto dos trabalhadores espanhóis da Estrada de Ferro Bahia-Minas, em 1884, cf. MELO, op. cit., p. 61-67.

21 Cf. MELO, op. cit., p. 65. O autor faz referência ao documento: Colônias e colonos. Colonos espanhóis. 1884, p. 1. Série Secretaria da Agricultura, seção colonial e provincial, maço 4.607-1, APEB. 
mais vulneráveis e vivenciando condições de trabalho indignas. Das mais variadas formas, os operários protagonizaram protestos e denunciaram o desrespeito e as arbitrariedades às quais estavam sendo submetidos pelos representantes da companhia da Bahia-Minas, conforme demonstra documento acionado por Melo:

\begin{abstract}
así en vista de todos estos trabajos dándole las quejas a nuestro administrador y no encontrando en el piedad para socorrernos como padre nuestras miserias o queríamos en quejas por medio de un telegrama a Rio Janeiro a Agustín Pires y Compañía comunicándole nuestro estado y miserias, ni aún [puvera] fueron atendidas nuestras quejas hasta que nos vimos en la necesidad de emprender nuestra viaje à la Ciudad de Carabelas entregándonos a las autoridades para por medio de ellas ser justificada nuestras miserias y abandono que sin ser merecedores hallas estábamos pasando, por cujas más acciones han justificado nuestro derecho y no han querido aceptar los requerimientos que han presentado la Compañía de estrada de ferro Baía y Minas queriéndoles anudar con estafas al mismo Gobierno pidiéndole fuerzas para prendernos y levarnos amarrados a nuestras respectivas moradas balien. ${ }^{22}$
\end{abstract}

Em outro episódio em Caravelas, em 1885, alguns trabalhadores da ferrovia voltaram a se amotinar. Desta vez, conseguiram fazer com que muitos outros companheiros abandonassem o trabalho das oficinas. O engenheiro fiscal informou que, embora tivessem sido pagos e despedidos, aqueles operários continuavam a obstruir os trabalhos da ferrovia, o que levou à requisição de forças policiais para conter o motim e evitar maiores turbulências. ${ }^{23}$ Esse movimento foi debelado, mas no final da década novos conflitos envolvendo os trabalhadores da estrada de ferro voltariam a ocorrer, contribuindo para o clima de instabilidade e tensões que caracterizaram as sociedades escravistas nos anos finais do trabalho servil e no pós-abolição.

\title{
Caravelas e Vila Viçosa: escravidão e tensões no pós-abolição
}

Situada no extremo sul da BAHIA, a comarca de Caravelas incluía Vila Viçosa, onde estava localizada a Colônia Leopoldina. ${ }^{24}$ A colônia fora fundada em 1818 por alemães e se transformara rapidamente em uma empresa escravista. Segundo Carmo e Silva, "a Colônia Leopoldina podia ser considerada como o maior exemplo de propriedade sedimentada no regime de grande plantation fora do Recôncavo baiano". ${ }^{25}$ Dedicada sobretudo à plantação do café, à extração de madeira e à produção de farinha de mandioca, a região experimentara, no

22 Cf. MELO, op. cit., p. 66. O autor aciona o mesmo documento apontado na nota anterior. Através de análise cuidadosa das fontes, Melo apresenta análises fundamentais acerca das experiências daqueles trabalhadores imigrantes na região em questão.

23 Telegrama enviado por Epaminondas Ottoni, engenheiro fiscal, para o presidente da província, 6 de fevereiro de 1885. Estrada de Ferro Bahia-Minas, série viação, maço 4982, APEB.

24 A Colônia Leopoldina ficava situada no município de Vila Viçosa, atual Nova Viçosa, pertencente à comarca de Caravelas, no extremo sul da Bahia. CARMO, Alane Fraga do. Colonização e escravidão na Bahia: a Colônia Leopoldina (1850-1888). 2010. Dissertação (Mestrado em História) - Faculdade de Filosofia e Ciências Humanas, Universidade Federal da Bahia, Salvador, 2010. p. 16. CARMO, op. cit., p. 274; SILVA, op. cit., 2016, p. 86. 
século XIX, as várias formas de resistência escrava: formação de quilombos, fugas individuais e coletivas, sublevações, disputas jurídicas pela liberdade etc. ${ }^{26}$

$\mathrm{Na}$ década da abolição, possuía ainda uma quantidade significativa de cativos e vivenciava a crescente instabilidade provocada pelas disputas em torno da aplicação das leis de emancipação gradual, pelas ações e "insubordinação" escravas e pelo movimento abolicionista. Em 1882 cerca de 200 escravos atiraram no feitor da fazenda Monte Christo, uma das maiores da região, e se amotinaram, recusando-se a trabalhar sob a alegação de que estavam sendo maltratados; entre as motivações da revolta estaria a troca de proprietário. ${ }^{27} \mathrm{Em}$ 1884 o alvo do protesto escravo agora seria um senhor: o fazendeiro José Antônio Venerote, proprietário da fazenda Mutum, fora assassinado "a cacetadas" em uma emboscada por seis escravos de sua propriedade. Mais uma vez, entre as causas do delito estaria a troca de senhor e a ameaça de serem vendidos para outros locais, já que o novo proprietário estava envolvido no tráfico interprovincial. ${ }^{28}$ Segundo Ricardo Silva, os cativos poderiam ter agido também influenciados pela propaganda abolicionista na região - alguns contemporâneos atribuíam as ações escravas aos conselhos e influência de agitadores antiescravistas, que insuflavam os cativos contra os senhores. ${ }^{29}$

Em 1888 um novo conflito teria grande repercussão na província. No dia 19 de maio, por volta das 8 horas da noite, a filarmônica denominada Guarany, acompanhada do povo e dos libertos, comemorava a lei que aboliu a escravidão no Brasil pelas ruas da cidade de Caravelas, dando vivas ao Ministério e à princesa Isabel. Enquanto isso, da casa de um tal "Magro", onde "havia uns sambas", partiam vivas ao Partido Liberal" ${ }^{30}$ O confronto não demorou a acontecer, pois, ao passar pela casa, o grupo que festejava a lei provocou os integrantes do samba e todos entraram em luta corporal, resultando desta a morte de dois libertos de 13 de maio. O conflito envolvia questões de liberdade e disputas políticas entre conservadores e liberais locais. ${ }^{31}$

Nesse último conflito, há referências a trabalhadores da estrada de ferro Bahia-Minas: foram acusados do crime, entre outros, Valentim dos Santos Pedro, "crioulo, que foi empregado na companhia Bahia e Minas", e Felisberto da Silva Cabral, maquinista da companhia, também crioulo. Ambos residiam em Ponta de Areia, onde estavam situadas a estação central e as

26 CARMO, op. cit., p. 39, 59, 61-66, 115-118; SILVA, op. cit., 2016, p. 88-90. Segundo Silva, em comparação com outras regiões, as disputas pela liberdade na arena judicial não foram muito frutíferas no extremo sul. SILVA, op. cit., 2016, p. 107.

27 A sublevação na Fazenda Monte Christo foi analisada por CARMO, op. cit., p. 71-73 e por SILVA, op. cit., 2016, p. 91-94.

28 CARMO, op. cit., p. 78; SILVA, op. cit., 2016, p. 94-96

29 SILVA, op. cit., 2016, p. 95

30 Depoimento de Benedito Negro da Silveira, delegado 1884-1889, seção colonial e provincial, maço 3002, APEB.

31 A historiografia sobre a abolição na Bahia já analisou esse episódio, mas a participação de trabalhadores da estrada de ferro no evento não foi explorada. BRITO, Jailton L. A abolição na Bahia (1870-1888). Salvador: Centro de Estudos Baianos da UFBA, 2003. p. 235-237; MATA, lacy Maia. Libertos de 13 de maio e exsenhores na Bahia: conflitos no pós-abolição. Afro-Ásia, Salvador, n. 35, p. 193-196, 2007; ALBUQUERQUE, Wlamyra Ribeiro de. 0 jogo da dissimulação: Abolição e cidadania negra no Brasil. São Paulo: Companhia das Letras, 2009. p. 273-290; FRAGA FILHO, Walter. O 13 de maio e as celebrações da liberdade, Bahia, 1888-1893. História Social, Campinas, v. 1, p. 63-90, 2011. 
oficinas da estrada de ferro. Provavelmente, vieram, como muitos outros, para Caravelas "a fim de verem as festas da abolição do elemento servil". ${ }^{32}$ Já na noite de 12 de maio, antes mesmo da aprovação da lei, percorriam as ruas da cidade "uma mó de trabalhadores da estrada de ferro e ex-escravos dando vivas ao partido conservador e foras e morras aos liberais". ${ }^{33}$ Segundo o jornal, esse mesmo grupo, no dia 19,

já estando todos bastante alcoolizados, deixam os músicos os instrumentos, e de envolta com a capangagem dos trabalhadores da estrada de ferro e alguns ex-escravos, em marcha acelerada, tornam a percorrer as ruas, quebrando a cacete alguns lampiões da iluminação pública e proferindo ameaças aos liberais. ${ }^{34}$

Mapa 3 - Percurso da Bahia-Minas no município de Caravelas, onde começava a linha. A estação de Ponta da Areia está no estuário do rio Peruípe, a leste.

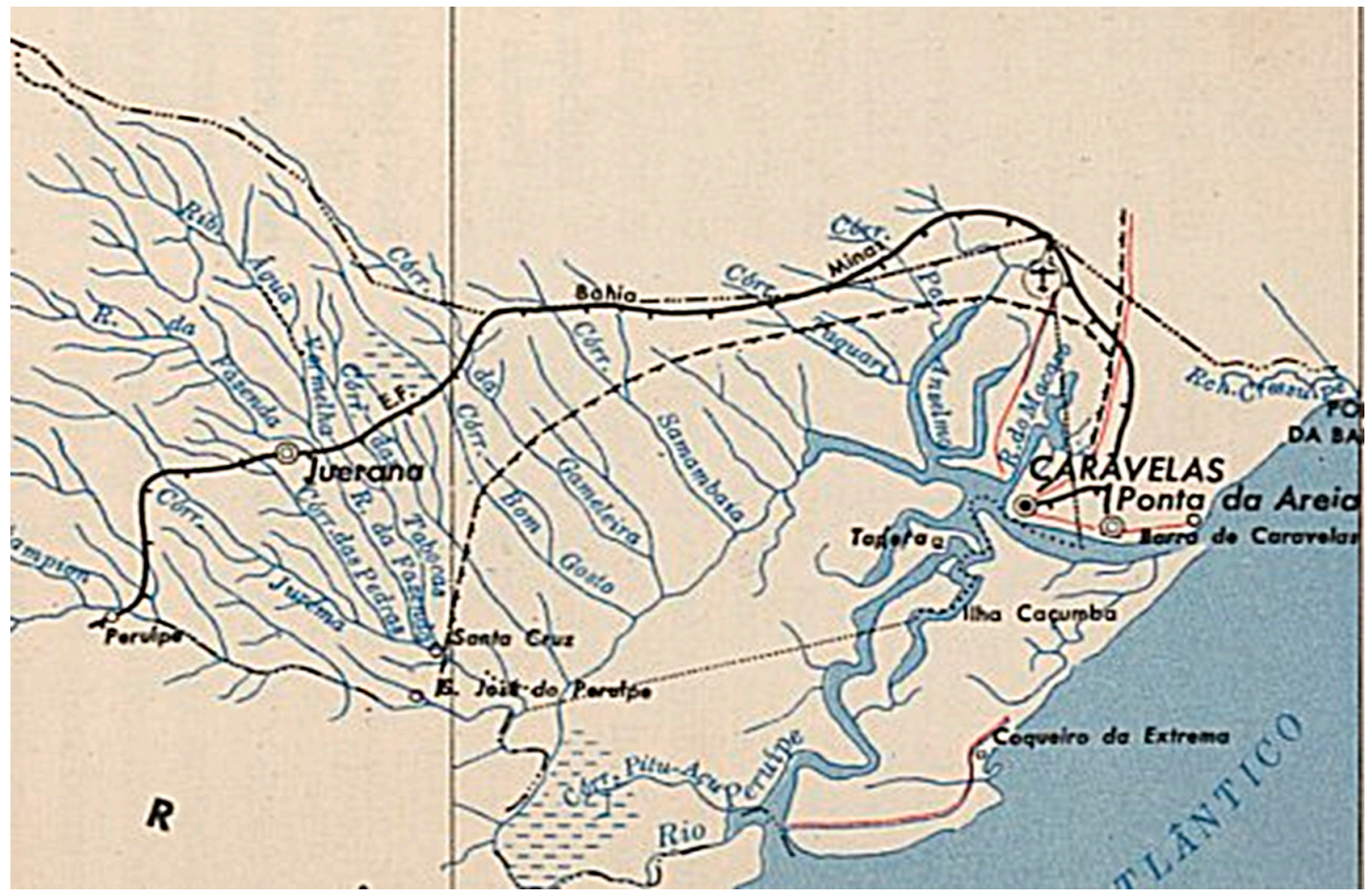

Fonte: Enciclopédia dos Municípios Brasileiros, volume VI, IBGE, 1958. Disponível em: http://www. estacoesferroviarias.com.br/baiminas/ponta.htm. Acesso em: 29 dez. 2016.

Ex-escravos e trabalhadores da ferrovia estavam, juntos, festejando a abolição na cidade de Caravelas. Antes da lei de 1888, há indícios da proximidade entre trabalhadores das estradas de ferro e alguns escravos na Bahia. Já no início do processo de implantação dos empreendimentos ferroviários, imigrantes e nacionais livres ou libertos conviviam diariamente e, às vezes, trabalhavam lado a lado com os cativos nos canteiros de obras. Além disso, escravos fugiam das senzalas e iam trabalhar clandestinamente nas ferrovias, passando-se

32 Depoimento de Benedito Negro da Silveira, delegado 1884-1889, seção colonial e provincial, maço 3002, APEB.

33 Diário da Bahia, Salvador, 14 jun. 1888. APEB.

34 Ibidem. 
por livres ou libertos. ${ }^{35}$ Não surpreende, portanto, que estivessem juntos a comemorar a lei que extinguia a escravidão.

A presença de trabalhadores da estrada de ferro Bahia-Minas no conflito envolvendo os libertosé ressaltada em vários documentos. Um deles destaca que os "turbulentos trabalhadores" foram chamados da Ponta de Areia para Caravelas na noite de 19, "apatrocinados" pelos chefes políticos conservadores da cidade, pelo encarregado da companhia Bahia-Minas e pelo médico assalariado por ela. Eles teriam percorrido as ruas desta cidade, dando "vivas insultuosas", desafiando os liberais e, "vendo [...] que não eram correspondidos, desabafaram suas iras, quebrando lampiões da iluminação pública." 36

Enquanto nesse episódio há apenas indícios da presença dispersa e residual de trabalhadores da estrada de ferro em episódios de disputas em torno dos significados da abolição, um evento, em especial, ainda não investigado pela historiografia, foi protagonizado pelos trabalhadores portugueses da empresa e contribuiu para alimentar o clima de intranquilidade, tensões e conflitos em torno dos significados do trabalho e da liberdade em uma sociedade recém-saída da escravidão.

\section{"Não pagava o preço que tratou na Corte": trabalho livre, protesto e insubordinação}

UM CONFLITO DE MAIORES PROPORÇÕES com os operários da ferrovia não tardou a acontecer. Em julho de 1888, o representante da estrada de ferro Bahia-Minas Dr. Fernando Pereira da Rocha Paranhos e o subdelegado da povoação de Aymorés requisitaram a força policial e a presença do delegado a fim de assegurar a ordem pública "alterada por um grupo de desordeiros em número superior a cinquenta, que armados desacataram ao empreiteiro-geral". A polícia era mais uma vez chamada para reprimir protestos dos trabalhadores da construção. Desta vez, trabalhadores portugueses da estrada de ferro protagonizaram um enfrentamento com o empreiteiro Alexandre Rodolfho Hehl, por volta das $11 \mathrm{~h} 00$, na ocasião em que o trem partia de Aymorés; no conflito, foram feridos o empreiteiro e o inspetor-geral da linha João Leopoldo Modesto Leal. Tudo começara um dia antes, quando dezenas de portugueses "estiveram todos armados de cacete na estação e no escritório do empreiteiro" para reclamar dos ordenados, alegando que "o patrão não pagava o preço que tratou na Corte". ${ }^{37}$

35 Em 1868, por exemplo, encontramos o fugitivo Basílio, que foi preso pelas forças policiais quando trabalhava como servente na estrada de ferro da Bahia ao São Francisco na Bahia, em Salvador. Cf. Ofício da Secretaria de Segurança de Polícia da Bahia, 27 de janeiro de 1868, série viação, seção colonial e provincial, maço 4968, APEB. Alguns anos mais tarde, na década de 1880, Manoel, preto, 38 anos de idade, fugiu dos olhos de sua senhora, d. Auta Elisa de Figueiredo, para trabalhar na construção da estrada de ferro em São Félix, no Recôncavo baiano. O chefe de polícia daquele distrito recebeu ordens para capturá-lo e enviá-lo de volta para Salvador, local onde certamente era escravo. Registro de correspondência com subdelegados (1879-1880), polícia, seção colonial e provincial, maço 5843, APEB.

36 Do vice-presidente da Câmara Antônio Jacintho da Silva Guimarães ao presidente da província, 22 de maio de 1888, correspondência recebida do correio - Telégrafo e Emp. Telefônica - 1850-1889, seção colonial e provincial, APEB.

37 No interrogatório, Francisco Teixeira Barros informou que "foi preso porque tendo o empreiteiro do 
Os portugueses Francisco Teixeira de Barros, João Loureiro, José de Souza Santos, José de Lima e Albino de Barros, considerados autores dos ferimentos e promotores das desordens, segundo algumas testemunhas, foram presos em flagrante por pessoas do povo. Os detidos foram apontados como "os desordeiros" empregados no prolongamento, "que já tinham sido despedidos do serviço por insubordinação". É interessante o uso da palavra "insubordinação" para definir protestos e reivindicações de trabalhadores livres. O termo foi muito usado nas Américas para definir comportamentos de ex-escravos que desafiavam e contestavam as hierarquias sociais e raciais. ${ }^{38}$ Nessa mesma região, dois meses antes, o subdelegado da Colônia Leopoldina solicitou força policial para conter os libertos de 13 de maio sob o argumento de que "o lar doméstico havia sido invadido pela insubordinação". ${ }^{39}$ Aqui, a palavra aparece sendo usada para descrever atitudes de trabalhadores envolvidos em protestos que reclamavam por direitos e justo pagamento salarial. A "insubordinação" de operários da estrada de ferro parece ter sido comum na região, pois, segundo o relato, a população de Aymorés vivia em sobressalto, uma vez que constantemente ocorriam eventos daquela natureza envolvendo os trabalhadores da construção da linha férrea. ${ }^{40}$

A tensão aumentou: os portugueses "desceram do serviço e vieram", agrupados e armados de pau, e aguardaram o empreiteiro dr. Helh na plataforma da estação quando este vinha de Caravelas. Assim que o empreiteiro chegou à estação, os trabalhadores o acompanharam até o escritório. Um dos envolvidos informou "que veio do serviço com seus companheiros que eram cinquenta e tantos para reclamar do empreiteiro". ${ }^{41}$ Apontado como "o cabeça destas desordens", o português Francisco de Barros informou que naquele dia o "patrão tratou mal a si e a seus companheiros, mas que afinal the prometeu pagar os dias vencidos a quatro mil réis, mas que ele e seus companheiros estavam despedidos". Segundo o seu depoimento, os portugueses vieram fazer a reclamação porque o encarregado do serviço lhes havia dito que "o patrão não pagava o preço que tratou na Corte". ${ }^{42}$ A resposta do empreiteiro às reclamações dos trabalhadores foi a demissão por insubordinação.

prolongamento da estrada de ferro contratado com ele, paciente, e seus patrícios na Corte pagar-lhes a quantia de 4:500 rs por dia não quis cumprir o trato, e sim pagar-Ihes diariamente o jornal de 3:300 rs"; por este motivo, depois dos 45 dias de residência e serviço, dirigiram-se ao escritório do empreiteiro para cobrarem o cumprimento do trato. Interrogatório de Francisco Teixeira Barros, recurso de responsabilidade 21/754/09, réu Adrelino Leite Barcelos e outros, Caravelas, 1889, seção judiciária, Tribunal de Justiça, APEB.

38 FONER, Eric. Nada além da liberdade: a emancipação e seu legado. Rio de Janeiro: Paz e Terra, 1988.

39 Subdelegado da Colônia Leopoldina ao chefe de polícia, Colônia Leopoldina, 28 maio1888, polícia, chefes de polícia 1878-1889, seção colonial e provincial, maço 2986, APEB; MATA, lacy Maia. Os 'treze de maio': ex-senhores, polícia e libertos na Bahia pós-abolição (1888-1889). 2002. Dissertação (Mestrado em História) - Faculdade de Filosofia e Ciências Humanas, Universidade Federal da Bahia, Salvador, 2002. p. 35; MAIA, op. cit., 2007, p. 195; ver também: FRAGA FILHO, Walter. Encruzilhadas da liberdade: histórias de escravos e libertos na Bahia (1870-1910). Campinas: Editora da Unicamp, 2006, p. 157; FONER, op. cit, p. 12, p. 97, p. 148; SILVA, Eduardo. Barões e escravidão. Rio de Janeiro: Nova Fronteira, 1984, p. 237.

40 Ofício do $2^{\circ}$ suplente do delegado de polícia de Caravelas ao chefe de polícia interino Altino Rodrigues Pimenta, Adrelino Leite de Barcelos, Caravelas, 26 jul. 1888, chefe de polícia, seção colonial e provincial, maço 2987, APEB.

41 Processo crime, 03/117/18, réu Francisco Teixeira de Barros e outros, Viçosa, 1890, auto de perguntas ao ofendido Francisco Teixeira de Barros, Tribunal da Relação, APEB.

42 Ibidem. 
No dia seguinte, 12, o conflito se acirrou. Quando o empreiteiro e o inspetor de linha estavam preparando o embarque no trem com destino ao prolongamento da estrada de ferro, uma turma de trabalhadores portugueses apresentou-se pretendendo embarcar, segundo alegaram depois, para pegar os pertences que estavam nos barracões. Os trabalhadores estariam armados de "cacete, foice, garrucha e faca". Proibidos de entrar no trem, por já estarem despedidos, resolveram forçar o embarque. Um deles conseguiu furar o bloqueio e subir no carro e, quando quase conseguia sentar-se, foi agarrado pela gola do paletó e posto para fora pelo inspetor, ao que reagiu descarregando-lhe "uma cacetada na parte superior do crânio". Esse foi o estopim para a briga generalizada que se seguiu; "o grupo apertou-se muito e as cacetadas rompiam de todos os lados". ${ }^{43}$ Em meio à confusão, tiros foram disparados, ninguém sabe exatamente de que direção, e atingiram o português Francisco de Barros e o trabalhador Pedro Romão Ferreira, que estavam em luta corporal.

"O motivo do conflito foi ter-se prometido aos denunciados um salário e se thes pagar outro". ${ }^{44}$ O não cumprimento dos acordos contratuais pelos empregadores das estradas de ferro foi fonte de tensões, disputas e reivindicações. Nos idos de 1859, trabalhadores imigrantes italianos, contratados pelo empreiteiro John Watson para trabalhar nas obras de construção da Estrada de Ferro da Bahia ao São Francisco, foram personagens de uma série de manifestações e insubordinações, motivadas, dentre outras questões, pelo descumprimento e pelo desrespeito dos empregadores com as condições contratuais, inclusive aquelas referentes ao valor e pagamento de salários. Insatisfeitos, os trabalhadores italianos denunciaram para a autoridade consular de seu país estabelecida na Bahia as precárias condições de vida e de trabalho a que estavam submetidos, além dos reduzidos rendimentos. ${ }^{45}$

O episódio de 1888 envolveu cerca de cinquenta portugueses e sete pessoas por parte da administração da estrada de ferro - o empreiteiro, o inspetor, a turma composta de quatro pessoas e o "feitor", que estavam todos sobre a prancha e iam partir para o prolongamento da estrada a fim de buscar madeiras. ${ }^{46} \mathrm{O}$ uso da palavra "feitor" parece estar aí para lembrar que, apesar de abolida a escravidão, as relações de trabalho livre insistiam em guardar reminiscências da escravidão.

No confronto, o inspetor foi ferido gravemente e não pôde prestar depoimento sobre o episódio; das lesões corporais, resultaram mutilação e deformidade de membros.

43 Nesse conflito não há certeza sobre o uso de armas de fogo pelos trabalhadores e não foi investigada a origem dos disparos; vários deles admitiram portar cacetes, que foram usados no momento da confusão: o trabalhador do canteiro de obras José de Lima, de 32 anos, informou ter estado no conflito, "com o seu cacete, com o qual costuma andar"; outro interrogado "confessa ter participado do conflito armado de cacete e que pretendia embarcar à força no trem". Interrogatório de José de Lima, interrogatório de Francisco Teixeira de Barros, que constam no processo crime 03/117/18, réu Francisco Teixeira de Barros e outros, Viçosa, 1890, Tribunal da Relação, APEB.

44 Depoimento da testemunha Pedro Sistório, que consta no processo crime 03/117/18, réu Francisco Teixeira de Barros e outros, Viçosa, 1890, Tribunal da Relação, APEB.

45 SOUZA, op. cit, 2015 , c. 4.

46 Sobre o papel do feitor no regime escravista, cf. LARA, Silvia Hunold. Campos da violência: escravos e senhores na capitania do Rio de Janeiro, 1750-1808. São Paulo: Paz e Terra, 1988. Para o ofício de feitor na estrada de ferro, cf. SOUZA, op. cit., 2011, p. 81. 
Aqui emergem as diferenças entre os trabalhadores da construção e os da operação da ferrovia. A multidão vista como ameaça à ordem é composta, sobretudo, por trabalhadores da construção da linha férrea - trabalhadores braçais, jornaleiros, sazonais, migrantes. $O$ inspetor, os maquinistas, os responsáveis pelo tráfego, empregados da empresa, eram, em geral, qualificados e ganhavam melhores salários. Nesse episódio tornam-se explícitas as cisões entre os trabalhadores - alguns se aliaram aos administradores da ferrovia, tentaram conter os portugueses e testemunharam a favor da empresa no processo judicial. Afloraram também as rivalidades nacionais: os portugueses acusaram os trabalhadores mineiros da ferrovia de terem efetuado sua prisão ilegal, sob a ordem da administração da empresa. 0 evento evidencia a complexidade do mundo do trabalho da construção das estradas de ferro e a destreza dos administradores em explorar e mobilizar as hierarquias, cisões e disputas internas que dividiam os trabalhadores. ${ }^{47}$

\section{"Metidos no tronco de pé": trabalho, punição e reminiscências da escravidão}

Após o confLITO, os portugueses esconderam-se em uma casa para pernoitar. Às três horas da madrugada foram surpreendidos por um grupo de mineiros armados de facão e garrucha. ${ }^{48}$ Alguns trabalhadores que estavam na casa conseguiram fugir, mas cinco deles que não obtiveram êxito na fuga foram presos e "conduzidos a uma sala de armazém na estação dos Aymorés e ali metidos no tronco de pé onde se conservaram até o dia 17 do mês de julho". ${ }^{49}$ Outros depoimentos foram unânimes em afirmar que, naquela ocasião, os portugueses foram presos em um armazém (depósito de toucinho), onde permaneceram "conservados no tronco" por cerca de quatro dias, sem que lhes fosse apresentada qualquer autoridade ou ordem legal da prisão. Alguns afirmaram ainda que durante esse período permaneceram incomunicáveis, sem comida e sem tratamento das feridas. ${ }^{50}$ Depois disso, os acusados ficaram presos nas cadeias de Caravelas e Viçosa por cerca de dois meses sem se lhes formar culpa e sem serem levados à presença da autoridade judicial. ${ }^{51}$

47 Segundo Luan Lima Batista, os operários da construção da Estrada de Ferro Central da Bahia, durante a greve de 1892, teriam ameaçado os maquinistas, o que nos aponta para as cisões internas daquele grupo de trabalhadores. BATISTA, Luan Lima. E... cuidado com o estômago! É uma víscera intolerante: experiências de trabalho, carestia e as lutas dos ferroviários da Estrada de Ferro Central da Bahia. (1875-1909). Dissertação (Mestrado em História) - Departamento de Ciências Humanas e Filosofia, Universidade Estadual de Feira de Santana, Feira de Santana, 2016.

48 Interrogatório de José de Souza Santos, que consta no recurso de responsabilidade 21/754/09, réu Adrelino Leite Barcelos e outros, Caravelas, 1889, seção judiciária, Tribunal de Justiça, APEB.

49 Interrogatório de José de Souza Santos, que consta no recurso de responsabilidade 21/754/09, réu Adrelino Leite Barcelos e outros, Caravelas, 1889, seção judiciária, Tribunal de Justiça, APEB.

50 Interrogatório de José de Lima, interrogatório de Albino de Barros, interrogatório de João Loureiro, que constam no recurso de responsabilidade 21/754/09, réu Adrelino Leite Barcelos e outros, Caravelas, 1889, seção judiciária, Tribunal de Justiça, APEB.

51 Conclusão e pedido de diligências que consta no recurso de responsabilidade 21/754/09, réu Adrelino Leite Barcelos e outros, Caravelas, 1889, seção judiciária, Tribunal de Justiça, APEB. 
$\mathrm{Na}$ Bahia pós-abolição, notícias de espancamentos, maus-tratos, castigos físicos, violências e agressões contra os libertos circularam nos jornais e na documentação policial. Houve denúncias de que ex-escravos foram presos no tronco (inclusive por autoridades policiais) e mantidos em cárcere privado por se recusarem a trabalhar. ${ }^{52}$ Apesar da aprovação das leis de emancipação gradual e da abolição em maio daquele ano, essa era uma sociedade moldada, forjada pela escravidão. Os métodos e instrumentos de tortura tradicionalmente usados contra os cativos não foram destruídos imediatamente com a aprovação da lei. Em alguns casos, as senzalas continuaram a existir e foram reaproveitadas como dormitório de trabalhadores. ${ }^{53}$ Embora esse não tenha sido um comportamento usual para os trabalhadores livres em geral, a prisão em tronco dos portugueses deixa pistas sobre as marcas da escravidão nas relações de trabalho livre na região no imediato pós-abolição. ${ }^{54} \mathrm{~A}$ arbitrariedade das prisões, o cerceamento da liberdade, o castigo físico e a falta de alimentação informam sobre até onde poderiam ir os métodos de coerção e disciplinarização da mão de obra livre em uma sociedade recémsaída da escravidão.

Mas outro fator aproxima a experiência dos trabalhadores portugueses presos da construção da estrada de ferro Bahia-Minas aos libertos na Bahia pós-abolição. O elo entre os dois grupos é um indivíduo, que assina como procurador dos portugueses no processo judicial que se seguiu à prisão: o padre Geraldo Xavier de Sant'Anna. ${ }^{55} \mathrm{O}$ pároco da Igreja de Nossa Senhora de Conceição de Villa Viçosa era abolicionista radical, republicano e líder local do Partido Liberal; participou de vários conflitos com proprietários de escravos e autoridades políticas, policiais e judiciais da região, deixando sobressaltados os escravistas de Vila Viçosa e Caravelas. Usando o púlpito para fazer calorosos discursos contra o trabalho servil e as injustiças da escravidão e denunciar crimes cometidos contra os escravos, foi acusado de fazer pregações aos cativos tratando sobre temas como a legitimidade do assassinato do senhor. ${ }^{56}$

Após a aprovação da lei de 13 de Maio, o padre Geraldo continuou sua obstinada luta contra a escravidão. No dia 19 daquele mês, em Vila Viçosa, o pároco participou com os libertos dos festejos em comemoração à lei, dando vivas à República e à abolição. Perto dali, na Colônia Leopoldina, até o dia 15 de maio, segundo a autoridade policial, as fazendas estavam funcionando normalmente até que o padre Geraldo, sem permissão dos proprietários,

52 MATA, op. cit., 2007, p. 13-18.

53 Ibidem, p. 13-14.

54 Para Gloria García Rodríguez, em regiões de plantation, livres, em especial negros e mulatos, queixaram-se de serem tratados como escravos. GARCÍA RODRÍGUEZ, Gloria. Conspiraciones y revueltas. La actividad política de los negros en Cuba, 1790-1845. Santiago de Cuba: Editorial Oriente, 2003. p. 235; MATA, lacy Maia. Conspirações da raça de cor: escravidão, liberdade e tensões raciais em Santiago de Cuba. Campinas: Editora da Unicamp, 2015. p. 61.

55 Do padre Geraldo Xavier de Sant'anna ao juiz municipal; procuração que consta no processo crime 03/117/18, réu Francisco Teixeira de Barros e outros, Viçosa, 1890, Tribunal da Relação, APEB.

56 Sobre o padre Geraldo, cf. GRADEN, Dale. From Slavery to Freedom in Brazil: Bahia, 1835-1900. Albuquerque: University of New Mexico Press, 2006. p. 317-318, 398 (a paginação aqui corresponde ao manuscrito inédito de 2001); CARMO, op. cit., p. 75-77; SILVA, op. cit., 2016, p. 84-109, p. 102-108. 
invadiu as fazendas e passou a conclamar os libertos a deixarem o serviço, pois já eram livres, incitando-os à desobediência e à vingança contra os castigos que sofreram no tempo da escravidão. ${ }^{57}$

Portanto, não é de estranhar o empenho do padre na defesa dos portugueses no processo judicial. A sua presença nos tribunais era constante e seu nome figurava como curador de escravos em processos criminais. ${ }^{58}$ Geraldo Xavier, ao que parece, colocava-se na arena jurídica na defesa de escravos, libertos e trabalhadores em geral contra os potentados locais. Como abolicionista radical, um dos destaques da sua atuação foi a denúncia de maus-tratos cometidos por proprietários e feitores a escravos da região. Talvez o ponto mais sensível para o padre, no episódio envolvendo os portugueses, tenha sido o uso do tronco como punição a trabalhadores livres mesmo depois da abolição. O recurso à violência e a um instrumento de punição tão associado à escravidão contra trabalhadores livres e libertos, mesmo após a abolição, remete ao debate mais amplo sobre escravidão e liberdade, continuidades e rupturas e o impacto do escravismo nas relações de trabalho no Brasil. Para o padre, talvez, a defesa dos trabalhadores portugueses significasse a continuidade da luta que travou durante anos contra a escravidão.

Na condição de seu representante legal, em 16 de agosto de 1888, o padre Geraldo Xavier deu entrada ao pedido de habeas corpus em prol dos trabalhadores da estrada de ferro. Na petição, o padre denunciou que as autoridades à frente do caso estavam mantendo injusta e ilegalmente os trabalhadores portugueses presos, argumentando principalmente que não foram observados protocolos jurídicos, a exemplo da formação de culpa no prazo máximo previsto na legislação, o que na sua visão violava direitos fundamentais e tornava a prisão uma arbitrariedade.

Provocados pelo padre, somente no dia 17 e 20 de agosto aqueles trabalhadores foram submetidos ao inquérito de qualificação, inclusive, quando questionados, afirmando não terem até aquele momento respondido a nenhum interrogatório na ocasião da prisão, o que sugere que as alegações de padre Geraldo acerca de total descumprimento das formalidades legais e arbitrariedades cometidas pelas autoridades policiais eram fundadas.

\section{Considerações finais}

Claudio Batalha informa como os trabalhadores urbanos, na Primeira República, estavam submetidos à punição dos patrões (ameaças de demissão, multas, cortes de salários, extensão de punição a outros membros da família etc.) e à ampla malha repressiva do próprio Estado, através da Polícia, do Exército e da Marinha, para neutralizar suas mobilizações por direitos.

$\overline{57}$ BRITO, op. cit., p. 235-237; MATA, op. cit., 2002, p. 193-196; ALBUQUERQUE, op. cit., p. 273-290.

58 O padre atuou como curador na defesa do escravo Laurindo, que, em um ato de desespero assassinou os dois filhos por não suportar mais presenciar a mulher ser castigada por estar cuidando deles. CARMO, op. cit. p. 76; SILVA, op. cit., 2016, p. 96-100. 
Considerando que estes aspectos moldariam as experiências e "os horizontes de liberdades" dos trabalhadores da Primeira República, Batalha critica o que chama de lugar comum na historiografia brasileira de explicar o recurso à violência e à coerção nas relações de trabalho no Brasil como continuidade repressiva da escravidão. Segundo ele, essa realidade teria sido comum nas relações de trabalho livres em sociedades que não conheceram o sistema escravista (ou em que este foi marginal). ${ }^{59}$

Se o passado escravista marca, ainda hoje, uma série de aspectos da sociedade brasileira, particularmente sob a forma de preconceito social e das formas de exclusão que atingem os afrodescendentes, o emprego da violência nas relações de trabalho, a exploração e a ausência de direitos estiveram presentes em toda uma série de sociedades que não passaram pela experiência escravista. ${ }^{60}$

No entanto, como afirma John French, há "uma forte e multifacetada continuidade em termos de escravidão e seus legados no Brasil rural e urbano". ${ }^{61}$ Para o autor, atitudes e comportamentos - exercício legitimado de autoridade, cultura política autoritária e paternalista, hierarquias, rituais de mando (mandonismo) - gestados ao longo da escravidão, mas atuantes mesmo após 1888, ${ }^{62}$ são algumas heranças da escravidão no mundo do trabalho brasileiro, que o tornaria diferente de outras sociedades que não passaram pela experiência escravista. Em casos em que se recorria à ostentação da arma de fogo e aventava-se o recurso do chicote por parte do gerente para reprimir trabalhadores, encontramos elementos importantes que sinalizam para o legado da escravidão nas relações de trabalho no pós-abolição, demonstrando "o mandonismo como o modelo dominante de autoridade que governou as relações interpessoais dentro das hierarquias sociais". ${ }^{63}$

É o que ilustra o caso dos portugueses presos no sul da Bahia no imediato pós-abolição. Em 1888 o uso do tronco como punição, a violência física e o cerceamento da liberdade vividos pelos trabalhadores da construção da estrada de ferro Bahia-Minas nos meses imediatos à abolição do trabalho servil indicam, de alguma maneira, a "força da escravidão"64 e a lenta e complexa transformação das relações de trabalho no Brasil. Neste episódio, sobressaem o legado, o peso e as reminiscências do cativeiro no mundo do trabalho e na formação da sociedade brasileira, ajudando-nos a compreender melhor os sentidos e os fios, ainda dispersos, que conectam a experiência da escravidão e da liberdade.

Mas esses eram trabalhadores portugueses e talvez por essa razão tenha sido aberto um processo judicial para investigar o uso do tronco e a arbitrariedade da prisão.

59 BATALHA, Claudio Henrique Moraes. Limites da liberdade: trabalhadores, relações de trabalho e cidadania durante a Primeira República. In: LIBBY, Douglas Cole; FURTADO, Júnia Ferreira (org.). Trabalho livre, trabalho escravo: Brasil e Europa, séculos XVIII e XIX. São Paulo: Annablume, 2006. p. 104

60 Ibidem, p. 109.

61 FRENCH, John. As falsas dicotomias entre escravidão e liberdade: continuidade e rupturas na formação política e social do Brasil moderno. In: LIBBY; FURTADO, op. cit., p. 77.

62 Ibidem, p. 78.

63 Ibidem, p. 91

64 CHALHOUB, Sidney. A força da escravidão. llegalidade e costume no Brasil oitocentista. São Paulo: Companhia das Letras, 2012. 
Afinal, como alegou o representante das vítimas, "os portugueses que foram levados presos para um salão de depósito da mesma estação dos Aymorés" foram aí mantidos num tronco contra a expressa disposição da lei e do art. 28 do Decreto n. ${ }^{\circ} 4.824$, de 22 de novembro de $1871 .{ }^{65}$ Os trabalhadores, com a ajuda do padre abolicionista, deram início a um processo tentando responsabilizar a autoridade policial e os administradores da estrada de ferro pela arbitrariedade e ilegalidade da prisão. No final, os portugueses foram libertados, mas não houve nenhuma punição para a empresa ou para os membros da força policial. Mas a luta jurídica dos operários e a percepção da não legitimidade do castigo e da prisão em tronco revelam que, embora prenhe de reminiscências escravistas, o contexto da abolição no sul da Bahia também abrigava, como os protestos revelam, um horizonte de expectativas de direitos e uma percepção de que a escravidão chegara ao fim.

Recebido em: 01/07/2020

Aprovado em: 09/072020

65 Recurso de responsabilidade 21/754/09, réu Andrelino Leite Barcelos e outros, Caravelas, 1889, seção judiciária, Tribunal de Justiça, APEB. O Decreto n. ${ }^{\circ}$ 4.824, de 22 de novembro de 1871, regulava a execução da Lei n. ${ }^{\circ}$ 2.033, de 24 de setembro do mesmo ano, que alterou diferentes disposições da legislação judiciária: "Art. 28. Além do que está disposto nos arts. 12 e 13 da lei, a autoridade que ordenar ou requisitar a prisão e o executor dela observarão o seguinte: o preso não será conduzido com ferros, algemas ou cordas, salvo o caso extremo de segurança, que deverá ser justificado pelo condutor; e quando não o justifique, além das penas em que incorrer, será multado na quantia de $10 \$ 000$ a $50 \$ 000$ pela autoridade a quem for apresentado o mesmo preso. O exemplar do mandado, a que se refere o citado art. 13, equivale à nota constitucional da culpa". Disponível em: http://www.jusbrasil.com.br/topicos/11294756/artigo-28-do-decreto-n-4824-de-22-denovembro-de-1871. Acesso em: 22 dez. 2016. 